\title{
AN EOCENE BITTACUS (MECOPTERA) ${ }^{1}$
}

\author{
By F. M. Carpenter \\ Harvard University
}

In $1928^{2}$ I described, as Palaeobittacus eocenicus, a species of the family Bittacidae from Eocene strata in Colorado. This has been the only representative of the Mecoptera in Eocene deposits and the earliest unquestionable record of a living family of the order. A second Eocene bittacid has now turned up, this time among an extensive collection of insects which Dr. Carl Parsons and I made nearly twenty years ago in Utah. It appears to be a true Bittacus with characteristic wing venation and body features.

\section{Genus Bittacus Latr.}

Bittacus egestionis, n. sp.

(Figures 1 and 2)

Fore wing: $8 \mathrm{~mm}$. long; maximum width, $2 \mathrm{~mm}$.; antennae $2 \mathrm{~mm}$. long; body $7 \mathrm{~mm}$. long; wings without mark-

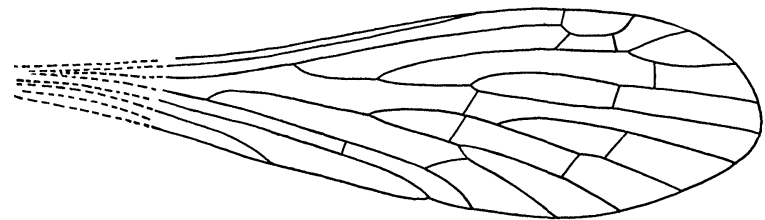

Figure 1. Drawing of fore wing of Bittacus egestionis, n. sp.

ings; venation and wing form as shown in figure 2 ; cubital cross-vein below the first fork of $\mathrm{M}$; two pterostigmal cross-veins apparently present; hing wings somewhat more slender than fore wings.

${ }^{1}$ Published with a grant from the Museum of Comparative Zoology at Harvard College.

${ }^{2} \mathrm{~A}$ Scorpion-fly from the Green River Eocene. Annals Carnegie Museum, 28: 240-249. 1928. 
Holotype: Museum of Comparative Zoology, No. 4921; collected by F. M. Carpenter and C. T. Parsons in the Evacuation Creek Formation, Green River Shales, about ten miles west of Evacuation Creek and the town of Watson, Utah. The fossil is very well preserved, showing antennae, legs, and all four wings; one pair of wings (fore and hind) rest together along the abdomen, but the other two extend below the body and are separated. The bases of the wings are partially concealed by the body of the insect and the veins there are not clearly preserved. The absence of copuloli and paraprocts shows that the specimen is a female.

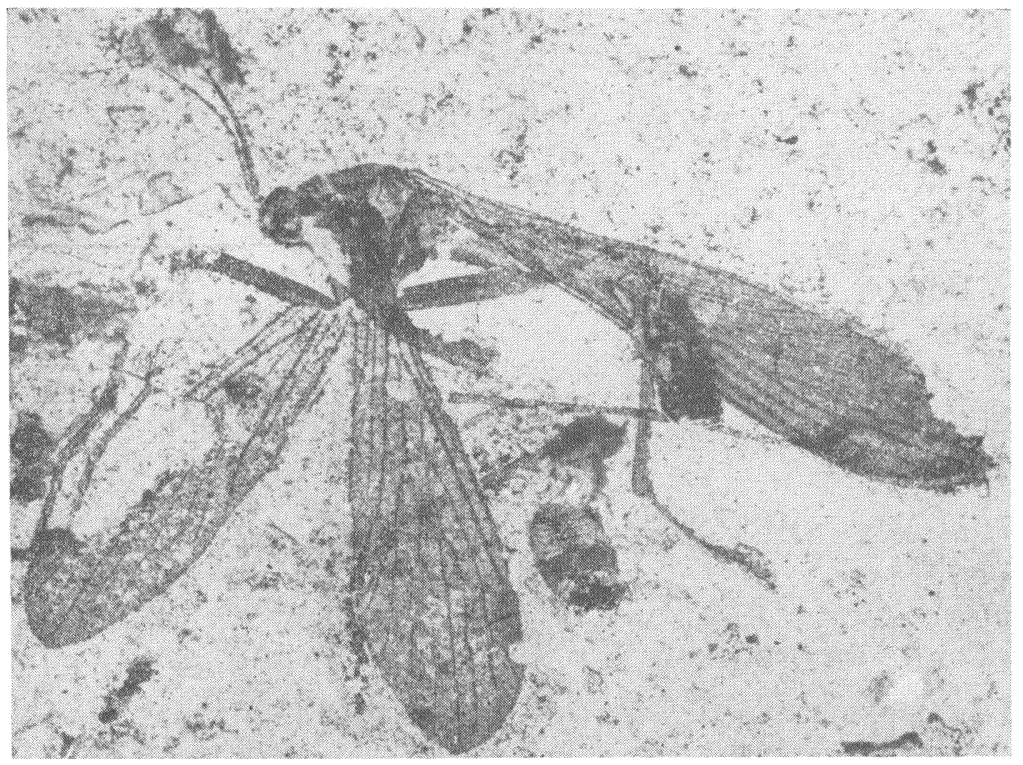

Figure 2. Photograph of Bittacus egestionis, n. sp., from the Eocene of Utah. Length of fore wing, $8 \mathrm{~mm}$.

Aside from generic differences this species differs from $P$. eocenicus by its more robust facies and smaller size. Its venation is typical of that of Bittacus, but the species is smaller than any other known in the family, so far as I am aware. In my account of the Baltic amber Mecoptera ${ }^{3}$, I pointed out that one of the amber species, Bittacus 
minimus, with a fore wing length of $11.5 \mathrm{~mm}$., was the smallest bittacid known; egestionis, with a fore wing 8 $\mathrm{mm}$. long, is even smaller. However, the other amber bittacids, as well as Palaeobittacus, show that not all of the early Tertiary Bittacidae were small; the range in size of these fossils is more an indication of the extent of the diversity of the family during Tertiary times.

${ }^{3}$ The Baltic Amber Mecoptera. Psyche, 61: 31-40. 1954.

The Southwestern Research Station of The American Museum of Natural History - The American Museum of Natural History has announced the establishment of The Southwestern Research Station. It is located on the eastern slope of the Chiricahua Mountains, near Portal, Cochise County, in southeastern Arizona. The property is within the limits of the Coronado National Forest at an elevation of 5400 feet.

The station was established for the purpose of making available research facilities for scientists and students in all branches of science, who have problems that can be investigated through the utilization of the faunal, floral and geological features of the area. It will be open during the entire year.

It is operated by the American Museum of Natural History, Central Park West at 79th Street, New York 24, New York and under the direction of Dr. Mont A. Cazier, Chairman and Curator of the Department of Insects and Spiders, to whom all inquiries should be addressed. Anyone interested in the station should write to the above named individual for the booklet which gives the details of the operation and a general description of the area. 

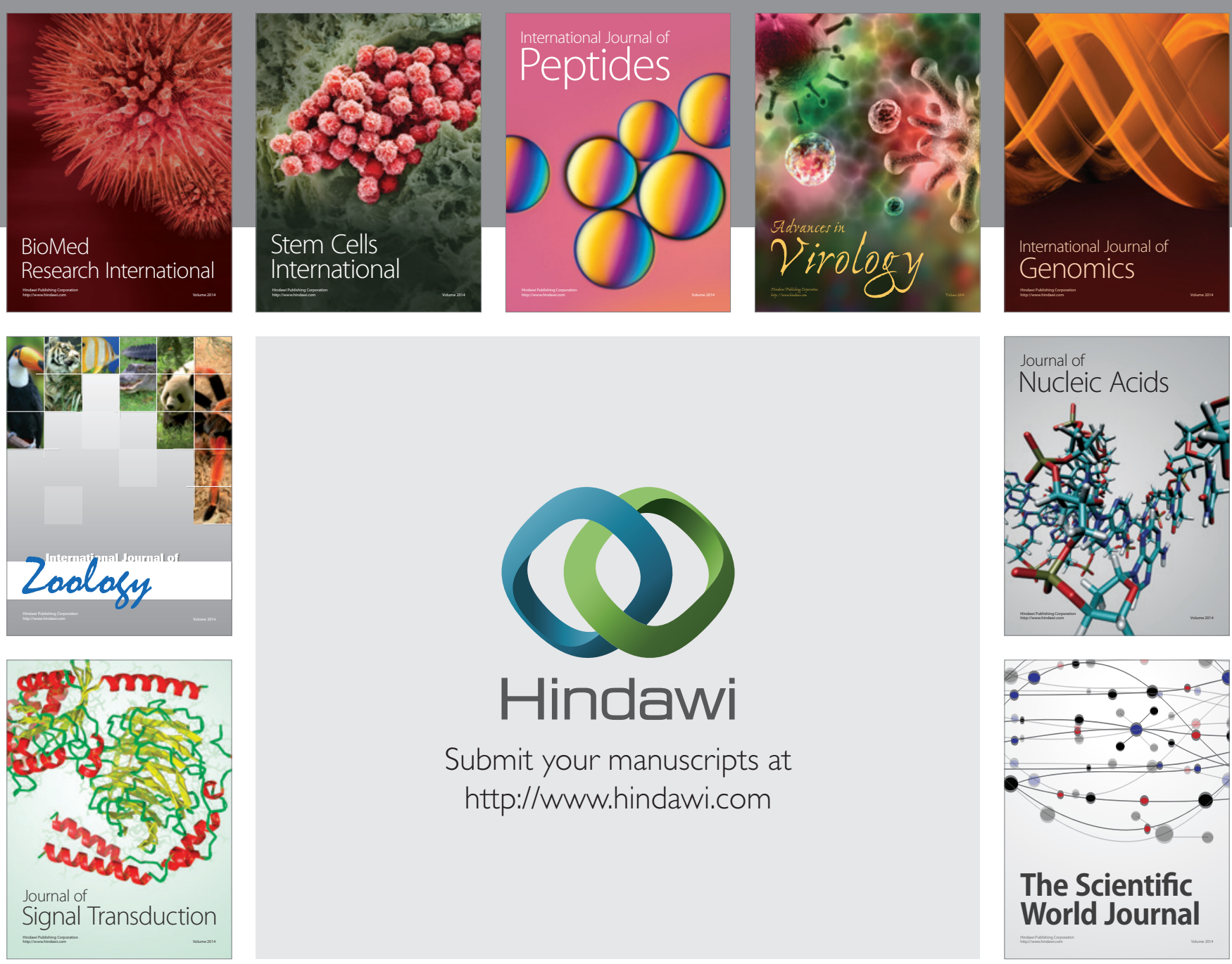

Submit your manuscripts at

http://www.hindawi.com
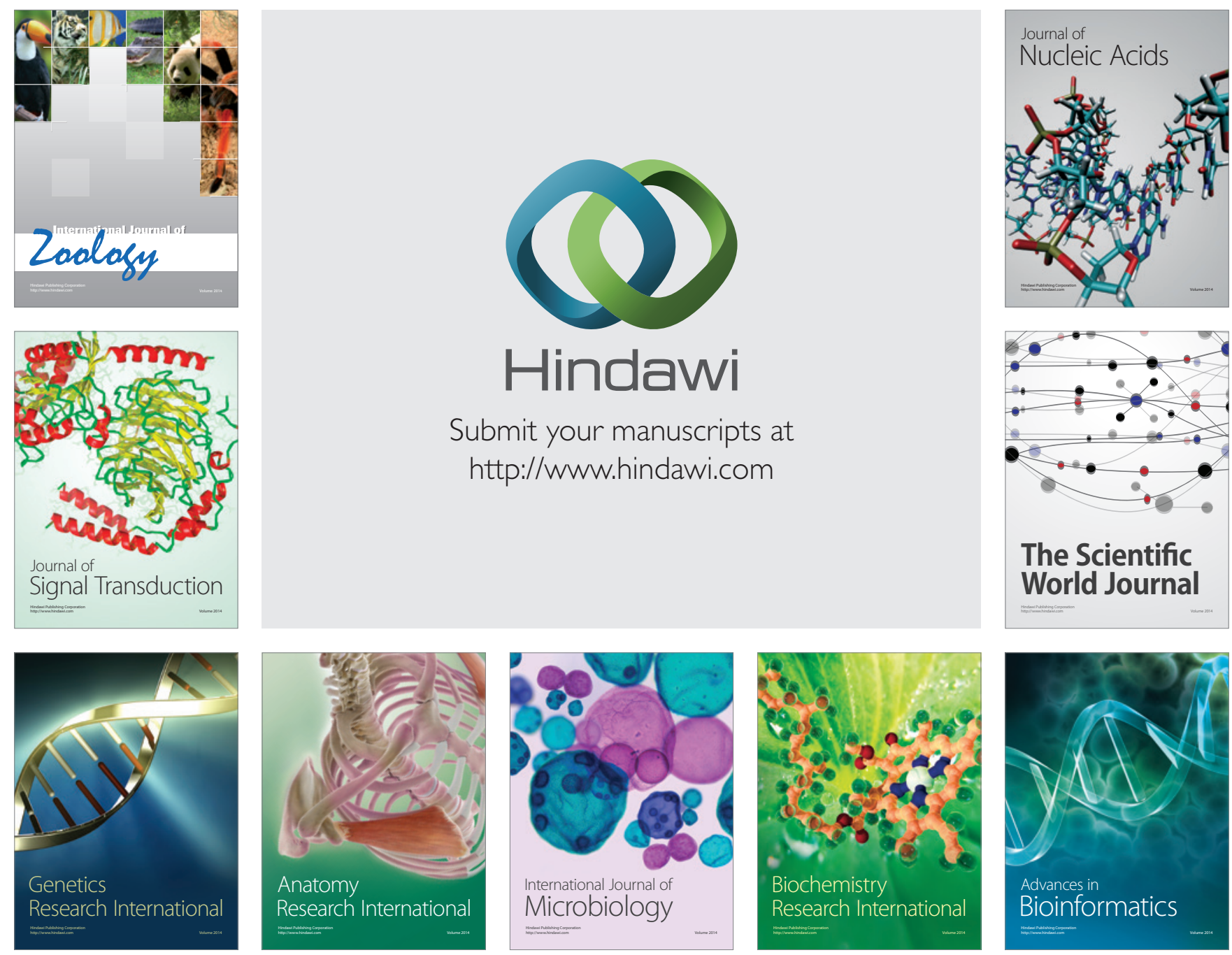

The Scientific World Journal
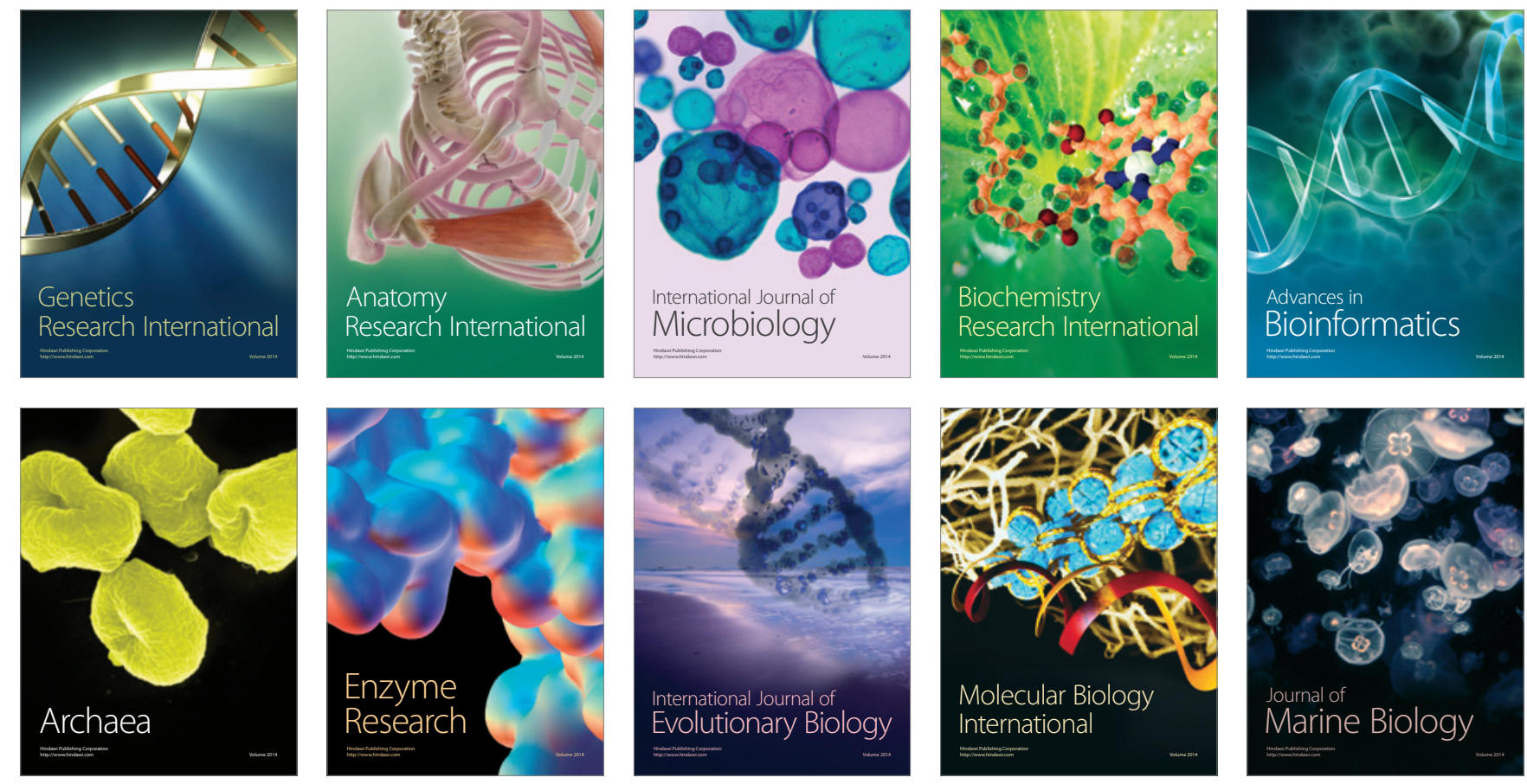